\title{
VISUALISASI STRUKTUR KRISTAL KERAMIK PEROVSKITE MENGGUNAKAN VESTA
}

\author{
Sundami Restiana ${ }^{1, *}$, Ari Sulistyo Rini ${ }^{2}$ \\ ${ }^{1}$ Mahasiswa Program Studi S-1 Fisika \\ ${ }^{2}$ Dosen Jurusan Fisika, \\ Fakultas Matematika dan Ilmu Pengetahuan Alam, \\ Universitas Riau Kampus Bina Widya \\ Jl. Prof. Muchtar Luthfi Pekanbaru, 28293, Indonesia \\ *E-mail: sundamirestiana@gmail.com
}

\begin{abstract}
Visualization of crystal structures and simulation of X-ray diffraction patterns of perovskite ceramic was successfully performed by VESTA software programs. The purpose of this research is to obtain the relation of lattice parameter, and composition to the diffraction pattern. The software program produces crystal structure information and a representative $X$-ray diffraction pattern for the ceramic materials. The program needs several input parameters such as the coordinates of each constituent atom, lattice parameters, and space symmetry. The obtained output of the software program are in the form of diffraction pattern graph and crystal structure data which gives the description of the profile and type (phase) of ceramic material. The results showed that the peak position and intensity of the diffraction pattern are influenced by the arrangement of the atoms within the unit cell. The addition of impurity atoms such as $\mathrm{Sr}$ on the $\mathrm{Ba}$ side in $\mathrm{BaTiO}_{3}$ causes the $\mathrm{BaTiO}_{3}$ structure changes from Orthorombic $(a \neq$ ) to Tetragonal $(a=b \#)$ structure. Based on the simulation, it can be predicted that the critical concentration of the change of structure occur at Sr concentration about 0.4.
\end{abstract}

Keywords : Visualization, Simulation, X-ray diffraction, VESTA, and RIETAN-FP.

\begin{abstract}
ABSTRAK
Visualisasi struktur kristal dan simulasi pola difraksi sinar-X dari keramik perovskite telah berhasil dilakukan dengan menggunakan program software VESTA. Tujuan dari penelitian ini untuk mendapatkan hubungan antara parameter kisi, dan komposisi terhadap perubahan pola difraksi puncak. Program software tersebut menghasilkan informasi bentuk struktur kristal dan pola difraksi sinar-X yang representatif untuk keramik $\mathrm{BaTiO}_{3}$ dan $\mathrm{Ba}_{1-x} \mathrm{Sr}_{x} \mathrm{TiO}_{3}$. Program ini membutuhkan input berupa koordinat masing-masing atom penyusun, parameter kisi, dan simetri ruang. Keluaran yang diperoleh berupa grafik pola difraksi dan data struktur kristal yang memberikan gambaran profil dan jenis (fase) bahan keramik. Hasil penelitian menunjukkan bahwa posisi puncak dan intensitas pola difraksi dipengaruhi oleh susunan atom dalam sel satuan. Penambahan atom pengotor seperti $\mathrm{Sr}$ pada sisi $\mathrm{Ba}$ dalam $\mathrm{BaTiO}_{3}$ menyebabkan terjadinya perubahan struktur $\mathrm{BaTiO}_{3}$ dari Orthorombik $(a \neq b \neq c)$ menjadi Tetragonal $(a=b \neq c)$. Berdasarkan hasil simulasi, dapat diprediksi bahwa konsentrasi kritis perubahan struktur terjadi pada konsentrasi $\mathrm{Sr}$ 0,4.
\end{abstract}

Kata kunci : Visualisasi, simulasi, diffraksi sinar-X, VESTA, dan RIETAN-FP.

\section{PENDAHULUAN}

Visualisasi struktur baik kristal dan elektronik memegang peranan penting untuk menerangkan sifat-sifat bahan/material. Sifat material dibangun atas dua konsep utama yaitu konsep struktur kristal atom dan konsep perlakuan terhadap bahan. Pengetahuan struktur kristal dari suatu bahan secara tidak langsung dapat memberikan informasi sifatsifat bahan [1].
XRD merupakan suatu metode karakteristik material yang paling mendasar dan paling banyak digunakan untuk menganalisis struktur kristal zat padat. Teknik ini tidak hanya digunakan untuk mengidentifikasi fasa kristalin dalam material tetapi juga komposisi fasa, struktur kristal dan mikrostruktur fasa-fasa didalamnya [2].

Penentuan struktur kristal secara manual memiliki kelemahan dari segi waktu dan akurasi. uatu program komputer. Penentuan 
struktur kristal secara manual Analisis struktur dengan menggunakan program komputer untuk dapat dilakukan dengan lebih cepat dan hasil akhir yang dikeluarkan komputer juga dapat diandalkan. Analisis struktur yang sering dilakukan adalah yang berbasis structure refinement menggunakan metode Rietveld [3].

Metode Rietveld dapat digunakan sebagai alat bantu karakteristik material kristalin untuk mengekstraksi berbagai informasi kimiawi maupun struktur mikro sebagai contoh analisis komposisi fasa dan menentukan parameter kisi secara akurat [4]. Beberapa software metode Rietveld yang dapat digunakan untuk menganalisa struktur kristal yaitu XRS-82 (The $X$-rays Rietveld System-82), FullProf, RIETANFP dan GSAS (General Structure Analysis System).

Keramik merupakan senyawa antara logam dan non logam yang memiliki bentuk struktur kristal yang menarik untuk dipelajari. Simulasi pola difraksi sinar-X telah dilakukan penelitian sebelumnya oleh yaitu mensimulasikan pola difraksi sinar-X berbagai jenis mineral zeolit alam dengan program RIETAN-FP [5]. Berdasarkan visualisasi struktur keramik yang telah didapat, diharapkan dapat dijadikan rujukan untuk menganalisa struktur-struktur material yang belum diketahui struktur kristalnya. Visualisasi struktur kristal masih jarang digambarkan secara jelas sehingga sulit memahami dan mempelajari strutur kristal. Dalam penelitian ini dilakukan visualisasi struktur kristal perovskite dengan menggunakan software VESTA dengan variasi komposisi.

\section{LANDASAN TEORI}

\section{Struktur kristal}

Sifat dan karakteristik dalam zat padat ditentukan oleh struktur kristal yang terdapat dalam material tersebut. Terdapat 7 macam sistem kristal dan kisi Bravaisnya [6] yang digolongkan berdasarkan jumlah sumbu kristal, letak sumbu kristal yang satu dengan yang lain, parameter yang digunakan untuk masing- masing sumbu kristal dan jumlah grup ruang yang diadopsi. Adapun ketujuh sistem kristal tersebut adalah seperti yang ditampilkan pada Tabel 1.

Tabel 1. Sistem kristal, parameter kisi, kisi Bravais dan jumlah grup ruang.

\begin{tabular}{|c|c|c|c|}
\hline $\begin{array}{l}\text { Sistem } \\
\text { Kristal }\end{array}$ & $\begin{array}{l}\text { Parameter } \\
\text { Kisi }\end{array}$ & $\begin{array}{c}\text { Kisi } \\
\text { Bravais }\end{array}$ & $\begin{array}{c}\text { Jumlah } \\
\text { Grup } \\
\text { Ruang }\end{array}$ \\
\hline Triklinik & $\begin{array}{l}u \neq b \neq v \\
u \neq \beta \neq \gamma\end{array}$ & $\mathrm{P}$ & 2 \\
\hline Monoklinik & $\begin{array}{l}u \neq b \neq v \\
u=\gamma \\
=90^{\circ} \neq \beta\end{array}$ & $\mathrm{P}, \mathrm{C}$ & 13 \\
\hline Ortorombik & $\begin{array}{l}u \neq b \neq b \\
u=\beta=\gamma \\
=90^{\circ}\end{array}$ & $\begin{array}{l}\mathrm{P}, \mathrm{I}, \mathrm{C}, \\
\mathrm{F}\end{array}$ & 59 \\
\hline Tetragonal & $\begin{array}{l}u=b \neq v \\
u=\beta=\gamma \\
=90^{\circ}\end{array}$ & $\mathrm{P}, \mathrm{I}$ & 68 \\
\hline Kubus & $\begin{array}{l}u=b=c \\
u=\beta=\gamma \\
=90^{\circ}\end{array}$ & $\mathrm{P}, \mathrm{I}, \mathrm{F}$ & 36 \\
\hline $\begin{array}{l}\text { Rhombohedral } \\
\text { /Trigonal }\end{array}$ & $\begin{array}{l}u=b=v \\
120^{\circ}>u \\
=\beta=\gamma \\
\neq 90^{\circ}\end{array}$ & $\mathrm{R}$ & 25 \\
\hline Hexagonal & $\begin{array}{c}u=b \neq v \\
u=\beta \\
=90^{\circ}, \gamma \\
=120^{\circ}\end{array}$ & $\mathrm{P}$ & 27 \\
\hline
\end{tabular}

\section{Difraksi sinar-X}

Difraksi sinar-X terjadi apabila seberkas sinar-X monokromatik dikenakan pada sebuah kristal sehingga atom-atom dalam kristal tersebut akan terhambur ke segala arah. Menurut Bragg, interferensi kontruktif terjadi bila panjang lintasan yang ditempuh sinar hamburan sejajar atau dengan kata lin selisih jejak sinar harus kelipatan bialngan bulat dari panjang gelombang $(\lambda)$ yang dapat ditulis dalam persamaan sebagai berikut [7].

$$
\mathrm{n} \lambda=2 \mathrm{~d}_{\mathrm{hkl}} \sin \theta
$$


Untuk menentukan struktur atom dari suatu kristal kubus sederhana dengan indeks miller (hkl) dan panjang kisi a jarak lintasan $\mathrm{d}_{\mathrm{hkl}}$ dapat dituliskan sebagai berikut:

$$
\mathrm{d}_{\mathrm{hkl}}=\frac{a}{\sqrt{h^{a}+k^{a}+l^{a}}}
$$

Sejumlah kontribusi dari seluruh atom dalam kisi dan hamburan terhadap posisi $\mathrm{x}, \mathrm{y}, \mathrm{z}$ didefinisikan sebagai faktor struktur yang dinyatakan dengan rumus berikut:

$$
\mathrm{F}=\sum_{n} f_{n} e^{2 \pi\left(h x^{+}+k y+l \hat{z}\right)}
$$

Dimana intensitas $I \sim|F|^{2}$. Intensitas berkas difraksi tidak hanya bergantung pada faktor struktur $|\mathrm{F}|^{2}$, tetapi ada faktor lain yaitu faktor multiplicity $(\mathrm{P})$, faktor polarisasi Lorentz (L), dan faktor suhu $\left(e^{-2 M}\right)[8]$.

$$
\mathrm{I}=\mathrm{F}^{2} \cdot \mathrm{P}\left(\frac{1+\mathrm{c}^{2} 2}{\mathrm{~S}^{2} \mathrm{\theta} \mathrm{C} \theta}\right) e^{-2 M}
$$

\section{Perovskite $\mathrm{Ba}_{1-\mathrm{x}} \mathrm{Sr}_{\mathrm{x}} \mathrm{TiO}_{3}$}

$\mathrm{BaTiO}_{3}$ (Barium titanat) mempunyai struktur kristal perovskite, di mana terdapat satu atom barium, satu atom titanium dan tiga atom oksigen. $\mathrm{Ba}$ dan $\mathrm{Ti}$ adalah kation besar yang dapat membentuk struktur rapat bersamaan dengan oksigen. Barium titanat memiliki sifat-sifat yang unik di mana sifatsifat tersebut berubah seiring dengan perubahan struktur kristalnya. Dalam struktur ini dimungkinkan untuk mensubstitusi sebagian dari kation-kationnya seperti dalam $\mathrm{Ba}_{1}$ ${ }_{x} \mathrm{Sr}_{\mathrm{x}} \mathrm{TiO}_{3} . \quad \mathrm{Ba}_{1-\mathrm{x}} \mathrm{Sr}_{\mathrm{x}} \mathrm{TiO}_{3}$ merupakan hasil campuran reaksi bahan barium carbonat, strontium carbonat dan titanium oksida.

\section{VESTA dan MATCH!3}

VESTA merupakan sebuah sistem visualisasi tiga dimensi dalam bahasa pemograman $\mathrm{C}++$ berdasarkan teknologi OpenGL untuk analisis elektronik dan struktural yang dikembangkan oleh Koichi Momma dan Fujio Izumi selama tahun 2001-
2004. Objek berupa atom, ikatan, koordinasi polyhedra, isosurfaces, dll dapat diputar, diskalakan, dan diterjemahkan dengan cepat dalam tiga dimensi. Skalabilitas dari VESTA sangat tinggi yang memungkinkan untuk menangani jumlah benda tak praktis yang hampir tak terbatas seperti atom, ikatan, polyhedra dan poligon pada isosurfaces asalkan kapasitas memori sudah cukup. Batas gambar didefinisikan oleh rentang sepanjang sumbu $\mathrm{x}$, y dan z serta bidang kisi [9].

VESTA dapat mensimulasikan pola difraksi serbuk dengan mudah melalui prosedur "Powder Diffraction Pattern" di bawah menu "Utilities". VESTA bertindak sebagai mediator antar struktur analisis dan kalkulasi struktur elektronik. Kesemua fitur canggih dan performa tinggi yang terdapat dalam program software VESTA diharapkan dapat memberikan kontribusi banyak untuk investigasi struktur kristal dan elektronik. Untuk melakukan visualisasi data yang diperlukan berupa koordinat atom penyusun di dalam kisi kristal, parameter kisi, dan group ruang. Data lengkap parameter struktur kristal dari beberapa jenis keramik diambil dari database JCPDS (Joint Committee on Powder Diffraction Standar), yaitu suatu badan pengumpulan data eksperimen difraksi sinar-X dari berbagai sumber yang dapat ditelusuri asalusul dan kebenaran datanya. Database ini dapat ditemukan pada software MATCH!3 yang merupakan sebuah perangkat lunak yang mudah digunakan untuk identifikasi fasa dari data difraksi serbuk.

\section{METODE PENELITIAN}

Penelitian yang dilakukan bertujuan untuk mensimulasikan struktur keramik perovskite $\mathrm{Ba}_{1-\mathrm{x}} \mathrm{Sr}_{\mathrm{x}} \mathrm{TiO}_{3}$ (BST) dengan variasi komposisi dan menganalisis pola-pola puncak difraksinya. Sampel yang digunakan berasal dari database JCPDS yang telah tervalidasi dan dapat ditelusuri asal-usul datanya. Data JCPDS yang digunakan diambil dari database software MATCH berupa bentuk struktur kristal dan parameter kisi. 


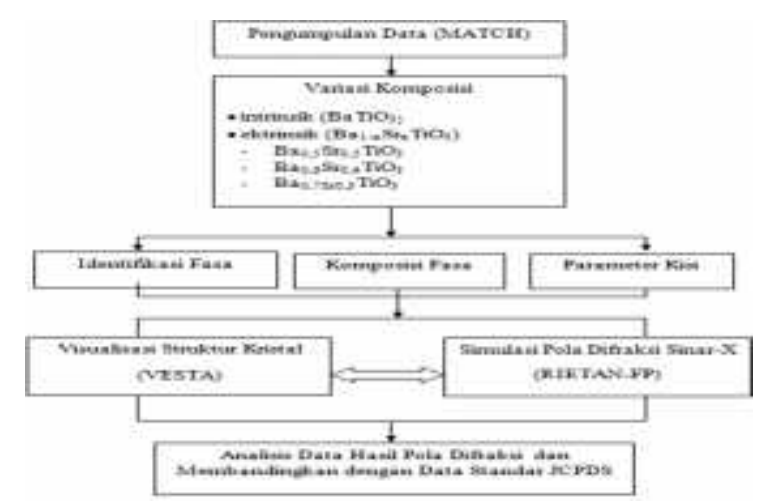

Gambar 1. Diagram Alir Penelitian.

\section{HASIL DAN PEMBAHASAN}

Pembahasan pada bab ini menampilkan hasil visualisasi struktur kristal dan simulasi pola difraksi sinar-X dari keramik perovskite BST dengan 3 variasi komposisi yaitu $\mathrm{Ba}_{0,5} \mathrm{Sr}_{0,5} \mathrm{TiO}_{3 ;} \mathrm{Ba}_{0,6} \mathrm{Sr}_{0,4} \mathrm{TiO}_{3}$ dan $\mathrm{Ba}_{0,7 \mathrm{Sr} 0,3} \mathrm{TiO}_{3}$.

Komposisi atom penyusun yang berbeda akan menghasilkan pergeseran pola-pola puncak difraksi dan bentuk struktur yang berbeda. Analisis dilakukan dengan membandingkan pola difraksi sinar-X untuk senyawa murni sebelum didopping yaitu $\mathrm{BaTiO}_{3}$ dengan senyawa yang telah didopping yaitu $\mathrm{Ba}_{1-\mathrm{x}} \mathrm{Sr}_{\mathrm{x}} \mathrm{TiO}_{3}$. Hasil visualisasi struktur kristal untuk variasi komposisi serta bentuk pola difraksi sinar-X dapat dilihat sebagai berikut:

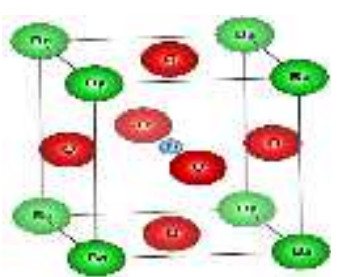

(a)

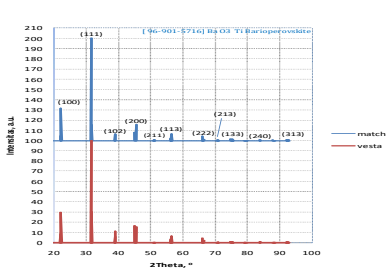

(b)
Gambar 2. (a) Visualisasi struktur kristal $\mathrm{BaTiO}_{3}$ dan (b) pola difraksinya.

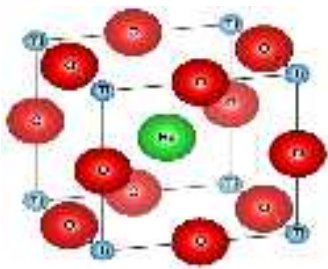

(a)

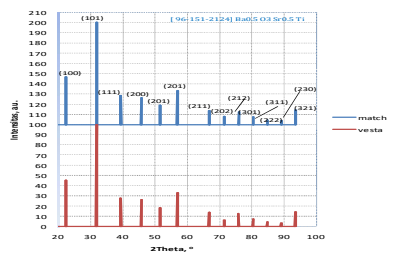

(b)
Gambar 3. (a) Visualisasi struktur kristal $\mathrm{Ba}_{0.5} \mathrm{Sr}_{0.5} \mathrm{TiO}_{3}$ dan (b) pola difraksinya.

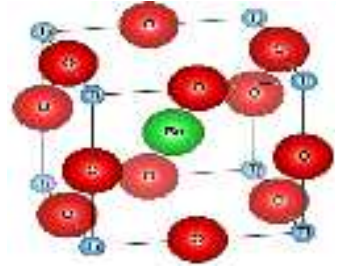

(a)

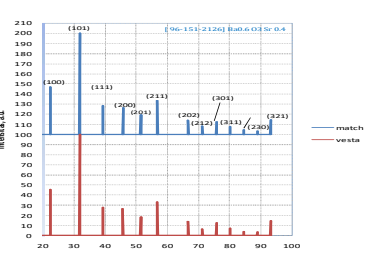

(b)
Gambar 4. (a) Visualisasi struktur Kristal $\mathrm{Ba}_{0.6} \mathrm{Sr}_{0.4} \mathrm{TiO}_{3}$ dan (b) pola difraksinya.

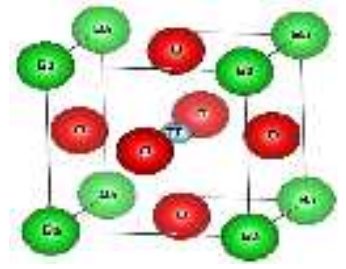

(a)

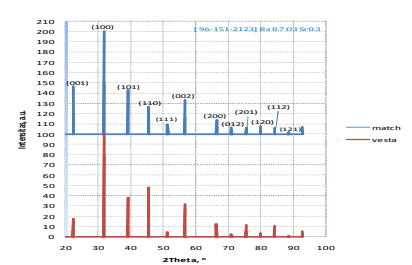

(b)
Gambar 5. (a) Visualisasi struktur kristal $\mathrm{Ba}_{0.7} \mathrm{Sr}_{0.3} \mathrm{TiO}_{3}$ dan (b) pola difraksinya.

Hasil simulasi pola difraksi sinar-X yang dibuat menunjukkan kesesuaian antara puncakpuncak hasil simulasi dengan puncak-puncak data referensi standar JCPDS, artinya visualisasi yang dibuat telah benar. Setelah didapatkan visualisasi yang benar kemudian dianalisis pengaruh perubahan struktur terhadap perubahan komposisi.

Komposisi penambahan $\mathrm{Sr}_{\mathrm{x}}$ yang berbedabeda yaitu $(x=0,3 ; 0,4$ dan 0,5$)$ mengakibatkan terjadinya perubahan pada parameter kisi dan juga pergeseran puncak maksimum pola difraksi ke arah sumbu x. Berikut ini disajikan pada Tabel 4.8 bentuk struktur dan harga parameter kisi hasil simulasi $\mathrm{Ba}_{1-\mathrm{x}} \mathrm{Sr}_{\mathrm{x}} \mathrm{TiO}_{3}$.

Tabel 2 Bentuk struktur dan harga parameterkisi hasil simulasi $\mathrm{Ba}_{1-\mathrm{x}} \mathrm{Sr}_{\mathrm{x}} \mathrm{TiO}_{3}$

\begin{tabular}{llccc}
\hline Senyawa & \multirow{2}{*}{ Struktur } & \multicolumn{3}{c}{ Paremeter Kisi } \\
\cline { 3 - 5 } & & $\mathrm{a}(\dot{\mathrm{A}})$ & $\mathrm{b}(\dot{\mathrm{A}})$ & $\mathrm{c}(\dot{\mathrm{A}})$ \\
\hline $\mathrm{BaTiO}_{3}$ & Orthoro- & 4,0094 & 5.6214 & 5.6386 \\
& mbik & & & \\
$\mathrm{Ba}_{0.7} \mathrm{Sr}_{0.3} \mathrm{~T}$ & Tetrago- & 3,9820 & 3,9820 & 3,9830 \\
$\mathrm{i} \mathrm{O}_{3}$ & nal & & & \\
$\mathrm{Ba}_{0.6} \mathrm{Sr}_{0.4} \mathrm{~T}$ & Kubik & 3,9690 & 3,9690 & 3,9690 \\
$\mathrm{i}_{3}$ & & 3,9560 & 3,9560 & 3,9560 \\
$\mathrm{Ba}_{0.5} \mathrm{Sr}_{0.5} \mathrm{~T}$ & Kubik & & & \\
$\mathrm{i}_{3}$ & & & \\
\hline
\end{tabular}


Semakin besar harga $\mathrm{x}$ dalam senyawa $\mathrm{Ba}_{1}$ ${ }_{x} \mathrm{Sr}_{\mathrm{x}} \mathrm{TiO}_{3}$, strukturnya akan cendrung berubah menjadi Tetragonal $(a=b \neq c)$ dan akhirnya menjadi Kubik $(\mathrm{a}=\mathrm{b}=\mathrm{c})$. Perubahan struktur ini diikuti dengan perubahan parameter kisinya, disatu sisi memendek dan sisi lain memanjang. Hal ini disebabkan oleh kecenderungan untuk membentuk struktur yang memiliki kerapatan atom per volume kisi yang tinggi.

Berdasarkan simulasi yang telah dilakukan dapat diprediksi konsentrasi kritis terjadinya perubahan struktur tersebut dengan memplot parameter kisi terhadap konsentrasi Sr yaitu pada konsentrasi sekitar 0,4.

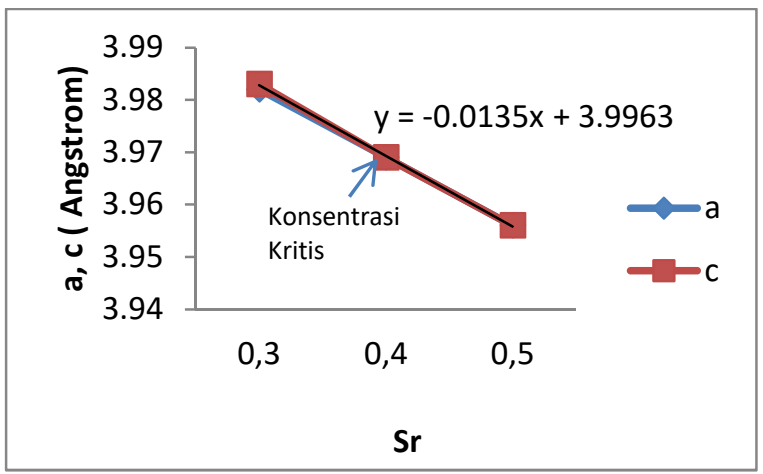

Gambar 6. Grafik Plot Sr vs parameter kisi a dan c.

\section{KESIMPULAN}

Visualisasi struktur kristal dan simulasi pola difraksi sinar-X dari keramik perovskite telah berhasil dilakukan dengan menggunakan program software VESTA. Pada variasi komposisi, perubahan $\mathrm{Sr}$ pada sisi $\mathrm{Ba}$ dalam $\mathrm{BaTiO}_{3}$ menyebabkan terjadinya perubahan struktur $\mathrm{BaTiO}_{3}$ dari Orthorombik $(\mathrm{a} \neq \mathrm{b} \neq \mathrm{c})$ menjadi Tetragonal $(a=b \neq c)$. Semakin besar harga $\mathrm{x}$ dalam senyawa $\mathrm{B}_{\mathrm{a} 1-\mathrm{x}} \mathrm{Sr}_{\mathrm{x}} \mathrm{TiO}_{3}$ maka strukturnya akan cendrung berubah dari Orthorombik $(a \neq b \neq c)$ menjadi Tetragonal $(\mathrm{a}=\mathrm{b} \neq \mathrm{c})$ dan akhirnya menjadi Kubik $(\mathrm{a}=\mathrm{b}$ $=\mathrm{c})$.

\section{DAFTAR PUSTAKA}

1. Surdia, T. \& Saito, S. (2005). Pengetahuan bahan teknik. Jakarta: PT. Pradnya Paramita.

2. Mittemeijer, E. J. \& Scardi, P. (2013). Diffraction Analysis of the Microstructure of Materials. Spring Science \& Business Media.

3. Rietveld, H. M. (1969). A Profile Refinement method for Nuclear and Magnetic Structure. Journal of Applied Crystallography, 2, 65-71.

4. O'Connor, B. H. \& Pratapa, S. (2002). Improving the Accuracy of Rietveldderived Lattice Parameters by an Order of Magnitude. Advances X-Ray Analysis, in Press.

5. Suminta, S. (2003). Simulasi Pola Difraksi Sinar-X Berbagai Jenis Mineral Zeolit Alam dengan Program RIETAN. Jurnal of Indonesia Zeolites, 2(1), 46-48.

6. Kittel, C. (1986). Introduction to Solid State 7th ed. New York: John Willey and Sons Inc.

7. Beiser, A. (1995). Fisika Modern. Jakarta : Erlangga.

8. Suryanarayana, C. \& Nortan, M. G. (1998). $X$-Ray Diffraction. New York, Plenum Press.

9. Momma, K. \& Izumi, F. (2011). VESTA : a Three- Dimensional Visualization of Crystal, volumetric and morphology data. Journal of Applied Crystallogr, 44, 12721276. 